\title{
1. Archival Objects and the Circulation of Culture
}

\begin{abstract}
Amanda Harris
Exchanges of cultural capital facilitated cross-cultural communication in a variety of Australian contexts, both before and after the arrival of Europeans in Australia at the end of the eighteenth century. In the absence of common languages on the colonial frontier, exchanges of music, dance, and painting can become tangible means of communication between people seeking to understand the culture of others. This book explores the circulation of ephemeral, physical and spiritual media across the lines that separate cultures from one another. Objects of cultural capital are transformed across landscapes and media through technology, people and their relationships with each other and with the otherworldly space beyond.

In his exploration of cross-cultural communication in Central and North America, Michael Taussig describes R. O. Marsh's use of the gramophone, as a means of navigating initial hostility between groups of meeting strangers: 'It proved to be an easy way for making an intercultural nexus, a new cultural zone of white and Indian social interaction for discovering strangeness and confirming sameness'. ${ }^{1}$ In his 1934 book, Marsh wrote:
\end{abstract}

After my experiences in the Darién I would never think of going into a 'wild' Indian territory without a phonograph. Time and time again we were to encounter surly, unfriendly, and even menacing Indians. We would appear to ignore them entirely. We would bring out and start a record while proceeding with our regular task of camp-pitching or what-not. The attention of the Indians would soon be diverted from us to the 'music-box'. Their hostility would cease and be replaced by curiosity. Gradually they would draw closer to the instrument, discussing it among themselves and finally would end up by crowding around it as closely as possible, touching and feeling it. From then on they would often keep us playing it until midnight, and were no longer our enemies though perhaps not yet our friends. ${ }^{2}$

1 Michael Taussig, Mimesis and Alterity: A Particular History of the Senses (New York: Routledge, 1993), 195. 2 Richard Oglesby Marsh, White Indians of Darien (New York: G.P. Putnam's Sons, 1934), quoted in Michael Taussig, Mimesis and Alterity (New York: Routledge, 1993), 194. 
Lacking the common language of customary behaviour to communicate intentions to the Indigenous peoples he encountered, Marsh combined the tools of cultural exchange and technology to forge a mode of communication that would transcend cultural boundaries.

This nexus of cultural capital and technology as a means to facilitate exchange and communication is a recurrent theme of the chapters in this book. We focus here, not only on non-Indigenous attempts to communicate through cultural capital with Indigenous peoples, but also look at the ways that culturally foreign technologies have been taken up by Indigenous and non-Indigenous communities alike in order to develop new ways of expressing culture. In doing so, our discussion engages not only with themes of cultural exchange but also thinks about modernity and the changing face of cultural practice in light of developing technologies.

\section{The Catalyst: The 1948 American-Australian Scientific Expedition to Arnhem Land}

The 1948 American-Australian Scientific Expedition to Arnhem Land, itself a project laden with the symbols of modernity, was the starting point for the collection of chapters that comprise this volume. Following a conference on the expedition in 2009 entitled Birds, Barks and Billabongs, Martin Thomas and Margo Neale published a collection that illuminated the expedition's ongoing legacy. ${ }^{3}$ That volume focused on the work of individual members of the expedition and the scholarly, artistic and cultural ramifications of the data and artefacts that they collected. The contributors to the current volume were brought together through a common interest in the expedition's project of gathering information about Aboriginal culture, bringing the tools of modernity to bear on study of the 'stone age', and its representation as a pioneering journey into the uncharted and undiscovered realms of Australia's wild north. However, for us, the expedition was a point of departure rather than subject matter in itself. For the contributors to this volume, it is not the context of the expedition which is the topic of their chapters, but rather what can be made of the circulation of cultural objects. These objects include both those collected on the venture into history-making that was the Arnhem Land Expedition, as well as broader materials involved in living, changing cultural practice. The authors journey well beyond the geographical limits of the expedition's camps in Arnhem Land to the west, north and over the seas.

3 Martin Thomas and Margo Neale, eds, Exploring the Legacy of the 1948 Arnhem Land Expedition (Canberra: ANU E Press, 2011). 


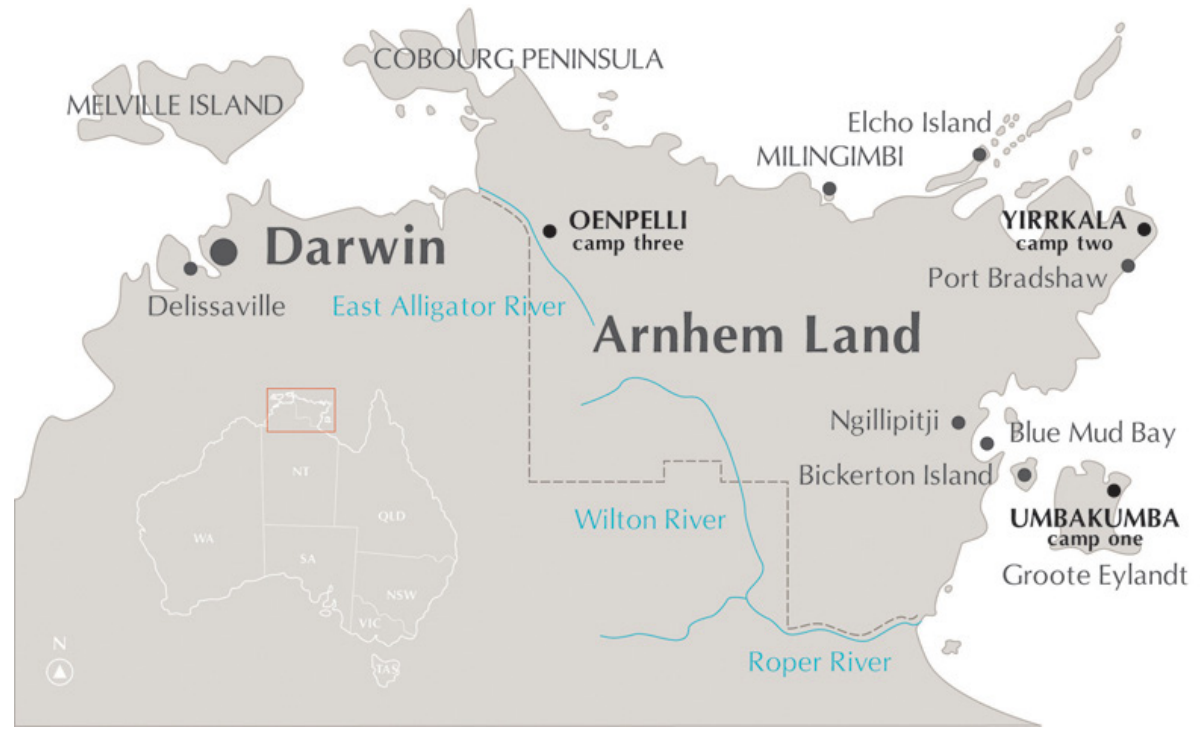

\section{Figure 1: Map showing the main sites visited by the Arnhem Land Expedition.}

Source: National Museum of Australia, reproduced with permission.

The 1948 expedition was in many ways an artefact of an earlier style of scientific expeditioning, immersed in notions of Aboriginal culture which were quickly becoming old-fashioned in modern anthropological circles, and representing itself as a pioneering project in spite of protests from anthropologists who had gone before. ${ }^{4}$ At the centre of the collection of cultural materials on the expedition was its leader, Charles Pearcy Mountford - amateur ethnographer, photographer, film maker and writer. Mountford's career as a student of Aboriginal culture, writer on Aboriginal art and touring film maker did not begin with the 1948 expedition. Rather, in the 1920s, Mountford had spent several years travelling through central Australia, building a collection of paintings and producing films not only about art but more broadly about Aboriginal culture. His interest in Aboriginal art and culture began while he was an employee of the General Post Office in Adelaide. After observing Aboriginal ceremonies in Darwin when he was transferred there in the early 1920s, he became interested in rock carvings in South Australia and Western New South Wales, and began visiting and making tracings of these, collaborating with the ethnologist Norman B. Tindale at the

4 See Sally K. May's discussion of the protests mounted by Ronald and Catherine Berndt and A. P. Elkin who had already worked in the area and who objected to Mountford portraying the area as 'the great unknown'. Sally K. May, Collecting Cultures: Myth, politics, and collaboration in the 1948 Arnhem Land Expedition (Lanham: AltaMira Press, 2009), 47-51. 
South Australian Museum to report on his findings. Mountford carried out this work with increasing enthusiasm and a growing public profile throughout the 1930s. His mounting expertise on central Australian art led to an appointment to a Commonwealth enquiry into the treatment of Aboriginal mission residents in Hermannsburg, and subsequently to participation in his first anthropological expedition, with the University of Adelaide, to the Warburton Ranges in 1935. This initial expedition was followed by five more through South Australia and the Northern Territory in the late 1930s. ${ }^{5}$

In the mid-1940s, Mountford was given the opportunity to tour the United States of America, showing two films he had made in 1942, Tjurunga and Walkabout. It was his presentation to the National Geographic Society in February 1945 that prompted the Society to invite Mountford to propose an expedition to Arnhem Land for their consideration. ${ }^{6}$ In the process of touring and showing the films throughout Australia and the US, Mountford distributed the products of his collecting far and wide, and came into regular and productive contact with artists and cultural practitioners of all kinds. As contributors to part one of this book elaborate, some of these interactions produced further artworks based on the Indigenous materials collected by Mountford, such as Mirrie and Alfred Hill's film music compositions, Beth Dean's ballet, and Margaret Preston's artworks. ${ }^{7}$ The musical recordings, art works and film footage collected by Mountford not only circulated geographically, but were also transformed, reinvented and reanimated by this circulation to create new art and cultural practice. Like much of the circulation of Aboriginal cultural materials in the mid-century, Mountford's publicisation of his collecting both drew attention to Aboriginal culture and stirred up controversy, sometimes causing offence. ${ }^{8}$

The recording of Indigenous culture in modern formats such as film enabled the dissemination of such ephemeral cultural materials as live performances not only throughout Australia, but to far distant places. Scholars of auditory histories have considered both what is lost and what gained by the transmutation of live performance into recorded forms that could be traded and distributed as cultural objects. Lisa Gitelman's discussion of North American blackface minstrelsy focuses on her attempts to hear 'through' the phonograph to the real

5 Max Lamshed, 'Monty': The biography of C. P. Mountford (Adelaide: Rigby, 1972), 28-49; May, Collecting Cultures, 38.

6 Sally May, 'The Art of Collecting: Charles Pearcy Mountford', in The Makers and Making of Indigenous Australian Museum Collections, eds Nicolas Peterson, Lindy Allen, and Louise Hamby (Carlton: Melbourne University Press, 2008), 450.

7 Nicolas Peterson, Lindy Allen, and Louise Hamby, eds, The Makers and Making of Indigenous Australian Museum Collections (Carlton: Melbourne University Press, 2008), 4.

8 For example, Olive Pink condemned Mountford's public showings of sacred material and was prompted by her reaction to this to keep the products of her own research restricted for 50 years, see Julie Marcus, 'The Beauty, Simplicity and Honour of Truth: Olive Pink in the 1940s,' in First in Their Field: Women and Australian anthropology, ed. Julie Marcus (Carlton: Melbourne University Press, 1993), 114. 
event. ${ }^{9}$ In intercultural exchanges through music recordings, Gitelman considers how race is masked and transmuted through the intervention of technology. While the voices and other sounds of the music makers remain in phonograph performances, the performer him or herself is obscured: 'By removing the performer from view, the technology of recorded sound also removed the most keenly felt representation of the performer's race. ${ }^{10}$

In the sound world of members of the 1948 Arnhem Land Expedition too, the tools of modernity with which they interacted (wireless transmitters, electronic recorders and other radio and sound forms) acted as points of contact between their own proudly modern project and that of the putatively stone-age, endemic, native culture of the Aboriginal people they observed. One of the means through which they sought to bridge the cultural divide was by recording the songs and ceremony of Aboriginal people they encountered in audio and film. In doing so, they converted the strangeness of the sounds heard in the alien surrounds of Arnhem Land into a format comprehensible to their own cultural parameters, a format that they could own, distribute and ultimately manipulate into other forms more readable or audibly intelligible. The Arnhem Land Expedition's participants made a public performance of this contrast of modernity and the stone-age in the popular media, reinforcing perceptions of the gulf between Indigenous and non-Indigenous Australian cultures. As Martin Thomas writes about the expedition's very public staging of their project: 'science must not only be done, but seen to be done by as large an audience as possible' ${ }^{11}$ This performance of science for the Australian public represented one face of the expedition, but was not necessarily reflective of the work being done by all of the expedition's members. Many of the scientists sought to carry out nuanced research which engaged with the cultures of Arnhem Land as rich, complex and culturally sophisticated societies, even while taking part in the public projection of the expedition as a triumph of modernity in contrast with an ancient culture.

The expedition's nutritionist, Margaret McArthur, is a good example of a scientist who sought to produce rigorous research, and politicised her work by speaking out for the Aboriginal people among whom she consulted and against the dehumanising practices of some of the missions she visited. ${ }^{12}$ The research McArthur published as a result of her work on the expedition documented the high nutritional value of local foods, and thus the balanced nature of the Indigenous diet, and showed that the diet commonly provided by missionaries

9 Lisa Gitelman, 'Recording Sound, Recording Race, Recording Property,' in Hearing History: A reader, ed. Mark M. Smith (Athens: University of Georgia Press, 2004), 280.

10 Gitelman, 'Recording Sound', 279.

11 Martin Thomas, 'Expedition as Time Capsule: Introducing the American-Australian Scientific Expedition to Arnhem Land,' in Exploring the Legacy of the 1948 Arnhem Land Expedition, eds Martin Thomas and Margo Neale (Canberra: ANU E Press, 2011), 18.

12 Amanda Harris, 'Chaperoned into Arnhem Land: Margaret Mcarthur and the politics of nutrition and fieldwork in 1948', Lilith: A feminist history journal 20 (2014): 62-75. 
for Aboriginal people was not only deficient but substantially inferior to the missionaries' own diets. ${ }^{13}$ A study that she co-authored with anthropologist Fred McCarthy in 1960 was later to become highly influential, and provided the data for Marshall Sahlins' theory of the 'Original Affluent Society', a corrective to evolutionary thinking about hunter-gatherer peoples which portrayed the hunters and gatherers of Arnhem Land as groups who enjoyed abundant leisure time, sufficient food and were not barely subsisting as previous anthropological approaches had suggested. ${ }^{14}$ In interviews with Colin Simpson, McArthur also argued that Aboriginal women enjoyed an empowered status in their society, evidenced by the carrying out of their own ceremonies and the fact that they danced and sang separately from the men. ${ }^{15}$ And yet, in spite of this attempt at a holistic conceptualisation of Aboriginal culture, McArthur too used the expedition's popular polarisations when publicising her work in the media. In a broadcast for the Women's Magazine of the Air in 1949 on group baby-minding in Arnhem Land, McArthur referred to her Aboriginal consultants as 'these stone age people', a term she was never to use in her scientific publications. ${ }^{16}$

The practices of the Arnhem Land Expedition were just one example of the cross-cultural grapplings with modernity occurring in Australia in the midto-late twentieth century. The kinds of productive circulation represented by Mountford's wide distribution of cultural capital have led the authors of this book to think about how music, dance and media move and are transformed in other ways in the Australian cultural landscape. The insights of the contributing authors bring ethnographic perspectives to broader international scholarship on objects and their movement across place and culture. In a related study, Maruška Svašek introduces three paradigms for thinking about the way the movement of objects and people interact with each other. Svašek invokes the processes of 'Transit', describing 'the changing social, cultural and spatial environments constituted by objects and individuals before and after coming into contact with each other'; 'Transition', identifying 'transit-related changes in the meaning, value and emotional efficacy of objects and images as opposed simply to changes in their location or ownership'; and 'Transformation', referring to 'transit-related changes in human subjects, specifically in terms of their status, identity formation and emotional subjectivity'. ${ }^{17}$ In the first four

13 See Margaret McArthur, 'Report on the Nutrition Unit,' in Records of the American-Australian Scientific Expedition to Arnhem Land, ed. Charles P. Mountford (Melbourne: Melbourne University Press, 1960), 1-143. 14 Frederick D. McCarthy and Margaret McArthur, 'The Food Quest and the Time Factor in Aboriginal Economic Life,' in Records of the American-Australian Scientific Expedition to Arnhem Land, ed. Charles P. Mountford (Melbourne: Melbourne University Press, 1960), 145-94; Marshall Sahlins, Stone Age Economics (Chicago: Aldine Atherton, 1972).

15 Colin Simpson, Adam in Ochre: Inside Aboriginal Australia (Sydney: Angus \& Robertson, 1951), 53.

16 Margaret McArthur, 'Script for Miss M. McArthur. Women's Magazine of the Air' McArthur, Annie Margaret [1919-2002], P205/1/2, University of Sydney Archives, 15 February 1949.

17 Maruska Svašek, ed., Moving Subjects, Moving Objects: Transnationalism, cultural production and emotions (New York: Berghahn Books, 2012), 2-5. 
chapters, our contributors think about how the long-lasting remnants of the 1948 expedition are still in circulation and transit today in various ways, as well as how both positive and negative consequences of the dispersal and transition of cultural materials have played out in modern Aboriginal communities. In the final four chapters, the transformation of cultural objects from their original context to new and distant ones brings out themes of newly forming identities and emotional subjectivities. These chapters take us well beyond the starting place of the original expedition, and bring the discussion of historical materials and circulation of culture into the present day.

\section{Histories of Collecting and the Context for Cultural Objects}

In their book The Makers and Making of Indigenous Australian Museum Collections, Nicolas Peterson, Lindy Allen and Louise Hamby define five key periods of collecting anthropological materials in Australian history:

1. From the first contact of Europeans and Aboriginal people to c. 1880collecting of materials was unsystematic;

2. c. 1880 until c. 1920 - collecting was influenced by social evolutionary theory, prompting the search for traditional stone technologies;

3. c. 1920 until 1940 - physical anthropologists sought to collect objects 'before it is too late';

4. 1940 to 1980 - research adjunct collecting, objects were collected as supporting documentation to the primary research being carried out;

5. 1980 to the present - a period in which the dominance of Aboriginal art is the focus of collections to the exclusion of almost anything else. ${ }^{18}$

Peterson et. al.'s five stages give a broad overview of collecting practices by nonIndigenous Australians (in particular physical anthropologists). While their stages do not fit every historical collecting scenario, they nevertheless provide a useful framework for thinking about the shifts in priorities in what Tom Griffiths has described as the Australian 'antiquarian imagination'. ${ }^{19}$ What is not included in these stages is an account of how Indigenous people interacted with the collecting of artefacts embodying their cultural heritage (more on this below).

18 Peterson, Allen, and Hamby, eds, The Makers and Making of Indigenous Australian Museum Collections, 8-12.

19 Tom Griffiths, Hunters and Collectors: The antiquarian imagination in Australia (Cambridge: Cambridge University Press, 1996). 
The starting point of most of the investigations in our current book was, like Peterson et. al.'s, also a series of collected things, not necessarily physical objects produced for practical daily purposes, but more ephemeral things, events, songs, ceremonies and performances that were recorded in both audio and visual formats. As I have already suggested, it could be argued that at least the public face of the expedition was trapped in the mores of a much earlier tradition of collection, correlating to stage two in the above list. However, in considering the motives of expedition collectors and the uses to which the objects of their collecting fervour have been put, we may add to Peterson et al.'s categories a sixth period in the collection of materials. This sixth stage, beginning with isolated efforts c. 1970 gained momentum and became widespread by 1990, and has seen collections steadily become the materials for living, ongoing cultural tradition, rather than static, permanent objects for preservation and observation. This shift in the function of collecting and collections has seen the increasing involvement of Aboriginal people in the curation and public representation of collections, as well as the repatriation of copies of collected objects and even the objects themselves to their communities of origin.

Though 1990 was not the first time that materials began to be repatriated to their home communities, and thus made available for reimaginings and renewed uses, the shift in that decade to repatriation not just of the physical ethnographic artefacts, but also of cultural objects such as recordings of music and dance, represents the beginning of a nation-wide (and indeed international) trend. These acts of repatriation followed on from earlier efforts to recognise what might matter to Aboriginal people in the management of Australian museum collections, a movement that began to take hold in the 1970s. ${ }^{20}$ Tom Griffiths documents the shift in museum practice in Victoria from the 1970s towards the inclusion of Aboriginal people in the curation of museum collections, and the changing focus on 'present people' instead of only 'past objects' ${ }^{21}$ Similarly, in 1978, the Australian Museum effected a 'major redirection of activities' in the

20 This movement is ongoing, and is indeed still in the process of definition. See Sandy O'Sullivan's argument: 'We are still, as Indigenous people, often not included in the most central of questions over policy and engagement, and instead relegated to consultation on isolated moments of representation.' Sandy O'Sullivan, 'Reversing the Gaze: Considering Indigenous perspectives on museums, cultural representation and the equivocal digital remnant', in Information Technology and Indigenous Communities, eds Lyndon Ormond-Parker, Aaron Corn, Cressida Fforde, Kazuko Obata, and Sandy O'Sullivan (Canberra: AIATSIS Research Publications, 2013), 147.

21 Griffiths, Hunters and Collectors, 95. See also Lancefield's survey of archives across the world (especially in the US), which found that by 1992, a significant number of archives were repatriating materials in their collections, or investigating the possibility of doing so. Robert C. Lancefield, 'Musical Traces' Retraceable Paths: The repatriation of recorded sound', Journal of Folklore Research 35:1 (1998): 51; Judith Gray's description of the Federal Cylinder Project's return of digitised early twentieth century wire recordings of Native American music to communities in 1985. Judith Gray, 'Returning Music to the Makers: The Library of Congress, American Indians, and the Federal Cylinder Project', Cultural Survival Quarterly 20:4 (1996); and Linda Barwick's return of Elkin recordings and photographs to Belyuen community in the 1990s, described in Linda Barwick, 'Turning It All Upside Down ... Imagining a Distributed Digital Audiovisual Archive', Literary and Linguistic Computing 19:3 (2004), 257. 
management of its Australian Aboriginal collection. ${ }^{22}$ In 1975, as Chair of the Aboriginal Arts Board of the Australia Council, Wandjuk Marika had surveyed bark paintings held by the Australian Museum, collected during the 1948 Arnhem Land Expedition (those collected included paintings by Marika and his father), see Figure $2 .{ }^{23} \mathrm{~A}$ few years later, following the participation of the Museum's Director and several staff members in the 1978 UNESCO meeting on 'The Role of Museums in the Preservation of Traditional Cultures', the Australian Museum radically changed its approach to its collections, implementing policies to employ and train Aboriginal people to work in Australian museums, and perhaps more significantly, consulting with Aboriginal people on the retention and disposal of secret/sacred material in their collections. The Museum also began to investigate the return of human remains, following the findings of the UNESCO seminar showing that Aboriginal people strongly wished for greater decision-making power in procedures affecting the representation and revitalisation of their cultural heritage. ${ }^{24}$

The active involvement of Aboriginal people in decisions about national and regional collections has engendered a radical shift in the meanings and purposes with which collected items are imbued. So too, the contributors to the present book discuss a range of ways in which archival things have become animated by their circulation amongst the descendants of their original creators and collectors. As part of their research, the collection of Indigenous materials has taken a collaborative turn where objects are no longer disembodied from their creators and preserved in distant locations, but rather, where cultural materials have come to be fluid, changing objects which circulate in the present, creating practices of the future. Such a shift, from collecting and exhibition as the end product, to collections as a means to further exchange, development and interaction, has been closely tied to advances in technology and mobility, especially to the availability since the 1990s of digital and therefore more portable, accessible and dispersible formats for archival materials. The return of historical and archival materials in digital forms has become central to discussions of technology in Indigenous Australia, as evidenced by the outcomes of recent conferences, the AIATSIS National Indigenous Studies Conference (2009) and the Information Technologies and Indigenous Communities Symposium (2010). In Lyndon Ormond-Parker et. al.'s summary of these discussions, repatriation

\footnotetext{
22 'Australian Museum', in Annual Report 1978-79, AMS112_1978-1979, Australian Museum Archives, accessed 15 July 2014, http://australianmuseum.net.au/Uploads/Documents/26912/AMS112_1978-1979_ lowres_web.pdf, 13.

23 I am grateful to Martin Thomas for bringing this visit to my attention. 'Australian Museum' in Annual Report 1974-75, AMS112_1974-1975, Australian Museum Archives, accessed 15 July 2014, http:// australianmuseum.net.au/Uploads/Documents/26908/AMS112_1974-1975_lowres_web.pdf.

24 'Australian Museum', in Annual Report 1978-79, AMS112_1978-1979, Australian Museum Archives, accessed 15 July 2014, http://australianmuseum.net.au/Uploads/Documents/26912/AMS112_1978-1979_ lowres_web.pdf.
} 
is firmly placed as a priority, the group's findings calling for 'increased support for programs which support the return to community based archives of digitised heritage objects, including photographs, audiovisual recordings and manuscripts from national repositories'.$^{25}$

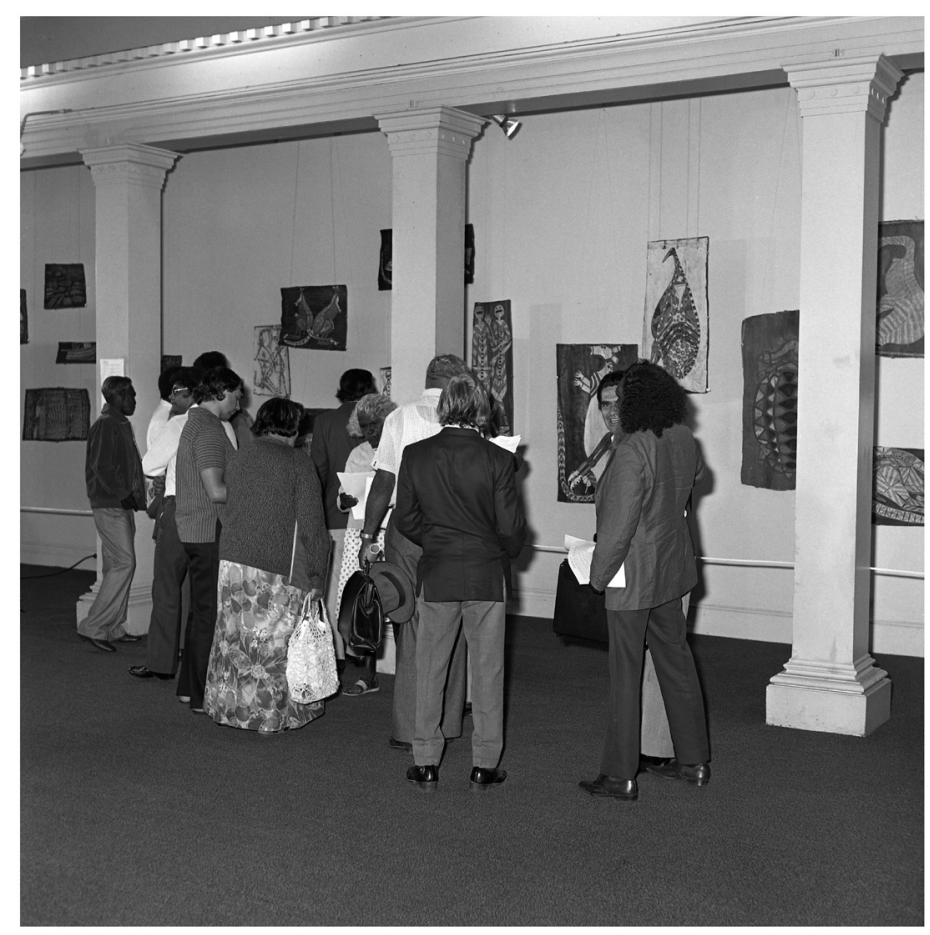

\section{Figure 2: Members of the Aboriginal Arts Board of the Australia Council visited the Australian Museum in April 1975 to inspect the Bark Painting Conservation Project.}

Source: Photograph by Gregory Millen, Australian Museum Series (AMS) 391/M606/11, reproduced with permission.

Cross-cultural exchange and the transformation of objects and traditions through cultural interaction has been the subject of several recent scholarly works. The product of postcolonial thinking about cultural materials, recent publications have focused on the way culture changes over time and place, distancing themselves from the anthropological focus on the 'other' and the accompanying search for authentic alien cultures. Studies of recent years have sought to demonstrate the cultural results of interaction and exchange which

25 Lyndon Ormond-Parker, Aaron Corn, Cressida Fforde, Kazuko Obata, and Sandy O'Sullivan, eds, Information Technology and Indigenous Communities (Canberra: AIATSIS Research Publications, 2013), xiii. 
are the product of fluid shifting cultures. Amiria J. M. Henare seeks to 'think through things' rather than through words or abstract ideas. Her Museums, Anthropology and Imperial Exchange (2005) documents the history and anthropology of artefacts in Scotland and New Zealand and the way these objects have been exchanged across cultures and places. Nicholas Thomas' Entangled Objects: Exchange, material culture and colonialism in the Pacific (1991) presents a history of the reciprocal appropriation of European and Indigenous objects and the transformation of ceremonies. A recent book edited by Fiona Magowan and Karl Neuenfeldt Landscapes of Indigenous Performance: Music, song and dance of the Torres Strait and Arnhem Land (2005) explores the metamorphosis of songs and performance traditions across cultures in Australia. And Fiona Richards' edited book The Soundscapes of Australia: Music, place and spirituality explores the way both Indigenous and non-Indigenous Australian music is bound to places of different kinds in the landscape. ${ }^{26}$ Circulating Cultures builds on the foundations of these cross-disciplinary studies, which create a history of colonial and postcolonial interactions through a focus on the creative arts and exchange of culture.

The chapters in this book focus on historical events, tracing the movement of culture through time and place in the last century, as well as current social frameworks and important cultural events occurring as recently as in the last two years. In part one, Victoria Haskins, Anthony Linden Jones and I discuss the fate of recordings of music and dance that began a journey of circulation with the 1948 Arnhem Land Expedition. In a chapter about the choreographer Beth Dean, Haskins places Mountford on the edge of a circle of women in the 1950s negotiating a new kind of transnational cultural circulation. Dean's meetings with Mountford in the United States of America led her on a journey to Australia and into the peculiar position of dancing the role of a male Aboriginal Initiate in a ballet set to signify Australian culture for the visit of Queen Elizabeth II in 1954. Haskins explores the cultural implications of an American woman embodying male Aboriginality on an Australian public stage, and places Dean within a culture of women's post-war transnationalism.

Mountford's recordings from the expedition also landed in the hands of nonIndigenous Australian composers Alfred and Mirrie Hill, and Jones' chapter on the compositions that were subsequently inspired by these recordings explores the circulation of music in film soundtracks in early Australian documentary films. Tracing the melodic and rhythmic themes of the Hills' compositions back

\footnotetext{
26 Amiria J. M. Henare, Museums, Anthropology and Imperial Exchange (Cambridge: Cambridge University Press, 2005); Nicholas Thomas, Entangled Objects: Exchange, material culture, and colonialism in the Pacific (Cambridge: Harvard University Press, 1991); Fiona Magowan and Karl Neuenfeldt, eds, Landscapes of Indigenous Performance: Music, song and dance of the Torres Strait and Arnhem Land (Canberra: Aboriginal Studies Press, 2005); Fiona Richards, ed., The Soundscapes of Australia: Music, place and spirituality (Aldershot: Ashgate, 2007).
} 
to songs collected in Arnhem Land in 1948, Jones shows that the soundtracks to Mountford's films represented a brave new world of film scores in the Australian tradition which moved away from the reliance on nineteenth-century European compositional styles.

Mid-twentieth century written descriptions of heard Aboriginal culture forms the subject of my chapter. Taking as my source material a selection of Australian novels, diarised accounts and a musical composition, I demonstrate that non-Indigenous listeners' ability to hear Aboriginal music in the bush was limited by projections of their own culture onto Aboriginal people. I show how themes such as the perceived innate or instinctual nature of Aboriginal musical expression and conflation of Aboriginal people with their surrounds - the land and animals - guided non-Indigenous hearing of the songs, rhythms and didjeridu playing of Aboriginal people in the bush. Incorporating the diaries of members of the Arnhem Land Expedition into my discussion, I show that non-Indigenous travellers' initial impressions of the music they heard were internalised as expressions of alienation and foreignness from the landscape and their surroundings, and that greater familiarity with Aboriginal culture sometimes created a window for listening to Aboriginal music with fresher and more informed ears.

In part two we explore the sixth period of the history of collecting, the repatriation, reanimation and revalidation of archival materials, discussing two instances of transformation of the meanings with which cultural objects are imbued. Part two opens with a chapter discussing the return of song recordings to the Tiwi Islands by Genevieve Campbell. Campbell explores how repatriated recordings have been received by the Tiwi community and have informed contemporary song composition, both as ceremony and entertainment. The music Campbell discusses spans a long period of collection, from Baldwin Spencer's 1912 recordings, through those of Colin Simpson and C. P. Mountford in 1948 and 1954, to recordings as recent as 1981. As Campbell charts the process of reclamation of song materials, she shows that one of the most significant factors in the reception of Palingarri (or 'long ago') songs by the Tiwi community has been the cultural owners' pro-active role in repatriating the songs.

In Martin Thomas' chapter, the consequences of removing bones from their resting place in Country and the result of repatriating those people back home, imbues the notion of objects with new meaning. Thomas' chapter documents historical accounts from 1948 of the deliberate theft of bones from their burial place on Injalak hill, outside of Gunbalanya (formally Oenpelli). ${ }^{27}$ Thomas contextualises the theft within the wider fervour of museum culture

27 The name Oenpelli originated in Paddy Cahill's mishearing of the local name Unbalanj as 'Owenpelly' in 1901. See Derek John Mulvaney, Paddy Cahill of Oenpelli (Canberra: Aboriginal Studies Press, 2004), 37. 
for building large collections of human remains from different cultures in the service of a science which sought to document a kind of evolutionary history of humankind. He explores the way that the assumptions of museum collectors such as Aleš Hrdlička and Frank Setzler acted as scientific validation for the politics of racial differentiation between Anglo-Europeans and the Aboriginal people of Australia. In his description of the ceremony that transported the bones from the Smithsonian Institution in the United States of America back to the Country of the deceased in the north of Australia, Thomas also discovers that for Aboriginal people, bones are anything but objects, rather they are the remaining physical manifestations of the spirits of the people to whom they belonged, spirits who can be communicated with and can communicate to the living in the languages spoken in their lifetimes. Thomas thus explores how theft and repatriation can be thought of as kidnapping and rescue with tangible and poignant meanings for the descendants of the deceased.

Part three offers three current perspectives on cross-cultural circulation and the investment of objects with new and transformed meanings. We remain in the Top End of Australia, beginning in Arnhem Land, but then journey beyond the reaches of the 1948 expedition and its collections, to the Daly region and the Kimberley. Reuben Brown takes as his starting point a funeral ceremony held in 2012 for a leader of the community of Gunbalanya. In interrogating the songs performed at this ceremony, Brown explores the ways in which music can accompany the travels of people's spirits and can move to link people from different places to each other. Locating the different songs used in the ceremony, Brown discovers that music can be understood as communication from the spirit world of one's ancestors. Brown's findings about the way music accompanies the remains of a person bound for burial in Gunbalanya hint at the importance of the burial of people on their own Country in Aboriginal cultures.

Sally Treloyn recounts her surprise at hearing a recording made in 1974 of Kimberley balga/junba songs, recorded, not in the Kimberley, but hundreds of kilometres away in Wadeye (formerly Port Keats). On playing the songs to the expert Kimberley balga composer Scotty Martin, Treloyn's suspicions of the songs' similarities were confirmed. Treloyn's chapter explores the implications of Martin's assertion that the Wadeye versions of the songs were 'cross and square', not only by exploring the variegation of musical features in the Wadeye and Kimberley songs, but also by mapping onto the region's geography the shapes created by Wurnan trade routes between Wadeye and the Kimberley.

In the final chapter, John Mansfield flips the discussion of repatriation of collected materials on its head and closes the book with an example of how an American and European subculture has been adopted by youth in the remote community of Wadeye. Mansfield shows how groups named after heavy metal bands and represented by their music and reimagined visual symbols have 
been mapped onto existing kinship systems. His chapter reveals how music heard on television and reaching increasingly wide distribution through recent technology, especially mobile phones, has been taken into circulation as a representation of group and kinship affiliations. The heavy metal music is thus broadcast from phones and home stereos and the symbols of metal culture have come to delineate areas of the community where members of a particular kinship group live.

\section{Conclusion}

All together, the chapters in this book present a portrait of new perspectives on circulating materials that have emerged in the twenty-first century. Building on Peterson, Allen and Hamby's classification of five historical periods of ethnographic collecting in the twentieth century, we illuminate a sixth stage of the handling of archival materials. Each chapter in this book contributes a unique perspective on the possibilities for bringing the static materials of the archive back into active circulation. By sharing, interacting with and circulating these objects, they have been imbued with new meanings and we discover some of the living possibilities of historical materials. As objects are returned to the communities from which they came, the descendants of their owners reanimate them with new lives and enliven their histories with new futures. We hope that these discussions make space for further explorations about how objects might be recirculated and may open the way for the revitalisation and reinvention of traditions both historical and continuing.

\section{Acknowledgements}

I am grateful for feedback that has helped to refine drafts of this chapter from Martin Thomas and two anonymous reviewers.

\section{References}

Barwick, Linda. 'Turning It All Upside Down ... Imagining a Distributed Digital Audiovisual Archive', Literary and Linguistic Computing 19:3 (2004): 253-63.

Gitelman, Lisa. 'Recording Sound, Recording Race, Recording Property', in Hearing History: A reader, ed. Mark M. Smith (Athens: University of Georgia Press, 2004), 279-94. 
Gray, Judith. 'Returning Music to the Makers: The Library of Congress, American Indians, and the Federal Cylinder Project', Cultural Survival Quarterly 20:4 (1996), http://www.culturalsurvival.org/ourpublications/ csq/article/returning-music-makers-the-library-congress-american-indiansand-federal\#sthash.3h2kgO2z.dpuf.

Griffiths, Tom. Hunters and Collectors: The antiquarian imagination in Australia (Cambridge: Cambridge University Press, 1996).

Harris, Amanda. 'Chaperoned into Arnhem Land: Margaret McArthur and the politics of nutrition and fieldwork in 1948', Lilith: A Feminist History Journal 20 (2014): 62-75.

Henare, Amiria J. M. Museums, Anthropology and Imperial Exchange (Cambridge: Cambridge University Press, 2005).

Lamshed, Max. 'Monty': The biography of C. P. Mountford (Adelaide: Rigby, 1972).

Lancefield, Robert C. 'Musical Traces' Retraceable Paths: The repatriation of recorded sound', Journal of Folklore Research 35:1 (1998): 47-68.

Magowan, Fiona, and Karl Neuenfeldt, eds. Landscapes of Indigenous Performance: Music, song and dance of the Torres Strait and Arnhem Land (Canberra: Aboriginal Studies Press, 2005).

Marcus, Julie. 'The Beauty, Simplicity and Honour of Truth: Olive Pink in the 1940s', in First in Their Field: Women and Australian Anthropology, ed. Julie Marcus (Carlton: Melbourne University Press, 1993), 111-35.

May, Sally. 'The Art of Collecting: Charles Pearcy Mountford', in The Makers and Making of Indigenous Australian Museum Collections, eds Nicolas Peterson, Lindy Allen and Louise Hamby (Carlton: Melbourne University Press, 2008), 446-71.

May, Sally K. Collecting Cultures: Myth, politics, and collaboration in the 1948 Arnhem Land Expedition (Lanham: AltaMira Press, 2009).

McArthur, Margaret. 'Report on the Nutrition Unit', in Records of the AmericanAustralian Scientific Expedition to Arnhem Land, ed. Charles P. Mountford (Melbourne: Melbourne University Press, 1960), 1-143.

McCarthy, Frederick D., and Margaret McArthur. 'The Food Quest and the Time Factor in Aboriginal Economic Life', in Records of the American-Australian Scientific Expedition to Arnhem Land, ed. Charles P. Mountford (Melbourne: Melbourne University Press, 1960), 145-94. 
Mulvaney, Derek John. Paddy Cahill of Oenpelli (Canberra: Aboriginal Studies Press, 2004).

Ormond-Parker, Lyndon, Aaron Corn, Cressida Fforde, Kazuko Obata, and Sandy O'Sullivan, eds. Information Technology and Indigenous Communities (Canberra: AIATSIS Research Publications, 2013).

O'Sullivan, Sandy. 'Reversing the Gaze: Considering Indigenous perspectives on museums, cultural representation and the equivocal digital remnant', in Information Technology and Indigenous Communities, eds Lyndon OrmondParker, Aaron Corn, Cressida Fforde, Kazuko Obata and Sandy O'Sullivan (Canberra: AIATSIS Research Publications, 2013), 139-49.

Peterson, Nicolas, Lindy Allen, and Louise Hamby, eds. The Makers and Making of Indigenous Australian Museum Collections (Carlton: Melbourne University Press, 2008).

Richards, Fiona, ed. The Soundscapes of Australia: Music, place and spirituality (Aldershot: Ashgate, 2007).

Sahlins, Marshall. Stone Age Economics (Chicago: Aldine Atherton, 1972).

Simpson, Colin. Adam in Ochre: Inside Aboriginal Australia (Sydney: Angus \& Robertson, 1951).

Svašek, Maruska, ed. Moving Subjects, Moving Objects: Transnationalism, cultural production and emotions (New York: Berghahn Books, 2012).

Taussig, Michael. Mimesis and Alterity: A particular history of the senses (New York: Routledge, 1993).

Thomas, Martin. 'Expedition as Time Capsule: Introducing the AmericanAustralian Scientific Expedition to Arnhem Land', in Exploring the Legacy of the 1948 Arnhem Land Expedition, eds Martin Thomas and Margo Neale (Canberra: ANU E Press, 2011), 1-30.

Thomas, Martin, and Margo Neale, eds. Exploring the Legacy of the 1948 Arnhem Land Expedition (Canberra: ANU E Press, 2011).

Thomas, Nicholas. Entangled Objects: Exchange, material culture, and colonialism in the Pacific (Cambridge: Harvard University Press, 1991). 
This text taken from Circulating Cultures: Exchanges of Australian Indigenous music, dance and media, edited by Amanda Harris, published 2014 by ANU Press, The Australian National University, Canberra, Australia. 